\title{
RESEARCH
}

Open Access

\section{Assessment of ecosystem services of rice farms in eastern India}

\author{
A. K. Nayak ${ }^{1 *}$, Md Shahid', A. D. Nayak', B. Dhal', K. C. Moharana', B. Mondal', R. Tripathi', S. D. Mohapatra', \\ P. Bhattacharyya' ${ }^{1}$ N. N. Jambhulkar ${ }^{1}$, A. K. Shukla², Nuala Fitton ${ }^{3}$, Pete Smith ${ }^{3}$ and H. Pathak ${ }^{1}$
}

\begin{abstract}
Background: Rice is a major cereal crop and staple food of eastern India, and most farmers depend solely on rice for their livelihood. Rice farming provides both tangible and non-tangible benefits to ecosystems which need to be maintained and enhanced. These benefits are provided through ecosystem services (ES) that include both marketable and non-marketable.

Methods: In this study, the rice farms in eastern India were valued by quantifying the economic value of the services under conventional method of rice cultivation and the gap of ecosystem services value and farm income per unit area were assessed. A stratified random sampling technique was used in this study for selection of agro-climatic zones, districts, blocks, gram panchayat, and study units (households). Soil sampling was also performed for assessing the regulating services (biocontrol of pests, carbon flow, soil erosion, nitrogen fixation), provisioning services (food and by-products), and supporting services (soil fertility, hydrological flow, nutrient cycling, and soil formation).

Results: The results indicated that the total economic value of ecosystem services ranged from US\$1238 to $1688 \mathrm{ha}^{-1}$ year $^{-1}$. The marketed (primary production) and non-marketed ecosystem services values ranged from $66-89$ to $11-34 \%$ of the total, respectively. Valuation of some of the ecosystem services such as cultural services, biodiversity, and gas regulation, which may play a significant role in total ecosystem services, has not been made due to non-availability of data and appropriate methodology for rice ecosystem. Different values of parameters can explain the variability in ecosystem services among the agro-climatic zones in eastern India. Clustering of locations based on variability of ecosystem services helps in identifying intervention points for sustaining and improving ecosystem services, while permitting sustainable agro-ecological intensification. The highest total economic gap between ES value and farm income was found in the north central plateau zone (US\$ $1063 \mathrm{ha}^{-1}$ year $^{-1}$ ) and the lowest in the north western plateau zone (US\$ $670 \mathrm{ha}^{-1} \mathrm{year}^{-1}$ ).
\end{abstract}

Conclusion: We suggest various measures to reduce the economic gap, including payments for ecosystem services for rice farming for sustainability of the ecosystem and agricultural development, while ensuring reliable farm income.

Keywords: Ecosystem services, Rice farming, Economic gap, Payment for ecosystem services (PES)

\footnotetext{
* Correspondence: aknayak20@yahoo.com; Ak.Nayak@icar.gov.in

${ }^{1}$ ICAR-National Rice Research Institute, Cuttack, Odisha 753006, India

Full list of author information is available at the end of the article
} 


\section{Introduction}

Agricultural ecosystems are engineered by humans to produce food, which is a basic need to sustain life and development. Apart from foods, they provide other valuable products such as fiber and fuel along with other non-marketed services to the environment (Costanza et al. 1997; Millennium Ecosystem Assessment (MEA) 2005; de Groot et al. 2012). The ecosystem services (ES) from farmland largely depend on the inputs used for cultivation and the crop management practices followed by farmers (Wossink and Swinton 2007; Ma et al. 2012). ES are usually classified as (a) provisioning services such as food, byproducts, fuel, and other harvestable goods; (b) regulating services like pest and disease control, pollination, soil retention; (c) cultural services like recreational and cultural benefits; and (d) supporting services, such as nutrient cycling, hydrological flow, and soil fertility that maintain the favorable conditions for life on Earth (MEA 2003).

Rice (Oryza sativa L.) is the staple food for 2.5 billion people worldwide, whereas in South Asia, about 1.7 billion people comprising over 50 million households, depend solely on rice for their livelihood (Manzanilla et al. 2011, IRRI Rice today 2014). In India, rice cultivation consumes about 32\% fertilizer (FAO 2005), 22\% of pesticide (Krishna et al. 2003), and about 60\% of water (Raju et al. 2005), and is cultivated on an area of about 43.4 million hectares (GOI 2016). Rice is widely grown in the eastern part of India; however, famers do not get adequate returns from rice cultivation in this region due to low productivity per unit of land. Thus, the government often pays compensation in the form of subsidies to the farmers. The valuation of ecosystem services has recently become an important area of research, aimed not only at maintaining and enhancing ecosystem services, but also for providing a solid platform for compensating the land managers for protecting, nurturing, and maintaining ecosystem services. Rice-based systems play a major role on both the supply- and demand-sides of ES (Zhang et al. 2007). They supply three primary categories of ES: provisioning, regulating, and cultural services, while they require supporting services in order to be productive. Farmers are the chief drivers of production through cultivation of crops, contributing to both food security and sustainable development (Tilman et al. 2002; Stalman 2011). The direct benefits of farming in the form of food, fiber, or fuel are provisioning services, which depend on the supporting and regulating services (Zhang et al. 2007). Farmers depend on these systems primarily for their provisioning services. Thus, proper management strategies are needed for continuous flow of these services. Apart from these $\mathrm{ES}$, rice ecosystems might also lead to disservices such as soil loss, nutrient depletion, the hosting of pests and diseases, and greenhouse gas (GHG) emissions (Zhang et al. 2007; Tilman et al. 2002; Barrios 2007; MEA 2005; Stallman et al. 2011). Life on the earth is supported by natural ES through numerous processes and functions (Myers 1996; Daily 1997). Decline of natural resources worldwide due to over exploitation has resulted in the loss of ES (Reid et al. 2005), necessitating that ES be accounted for through proper valuations. The aim of valuation is not simply to assign a price to ES goods and services, but is rather the process to promote the ES concept within governmental policy agendas (Loc et al. 2016). Literature on ES of agricultural ecosystems as a whole (Zhang et al. 2007; Ribaudo et al. 2010; Stallman 2011) has subsequently led to valuations of agricultural ecosystems (Sandhu et al. 2008; Xiao et al. 2011; Pathak et al. 2017), but little has been documented specifically on ES of rice-based systems.

Average farm household income in India is approx. Rs 8931 (128\$) per month, 2016 (National Bank for Agriculture and Rural Development (NABARD, 2017)). Such low farm income is primarily responsible for the prevailing agrarian crisis (Devi et al. 2017). Thus, many researchers have suggested that in order to increase the income of farmers, some minimum compensatory mechanism/allowance may be adopted/provided on the basis of a valuation of the ES that they generate. It has been reported that providing a monetary value for ES is an important step to raise awareness as well as convey the importance of ES to policy makers (Devi et al. 2017). To ensure the sustainability in rice farming in different environmental situations, and to improve the efficiency of production techniques, valuation of all services is necessary. There is a need to discover the reasons for the gaps between the total value of ecosystem services rendered by rice farming and economic return to the farmer (farm income) in terms of provisioning services. Thus, the present study was conducted to (a) estimate the value of ecosystem services from rice farms under different agroclimatic zones (ACZs), and (b) assess the gap between farm income and the value of marketed and non-marketed ES of rice farms in eastern India.

\section{Methodology}

\section{Study area, sample, and data}

The study area was in the eastern part of India (Fig. 1), where the climate is sub-humid tropical with mean annual precipitation ranging from about 1500 to $1600 \mathrm{~mm}$, of which $75-80 \%$ is received during June to September and the annual temperature ranges from 10.4 to $38{ }^{\circ} \mathrm{C}$, where rice is cultivated as the principal cereal crop. The detailed description of the study area is given in Table 1. A stratified random sampling technique was used to select the ACZs, districts, blocks, gram panchayat, and 


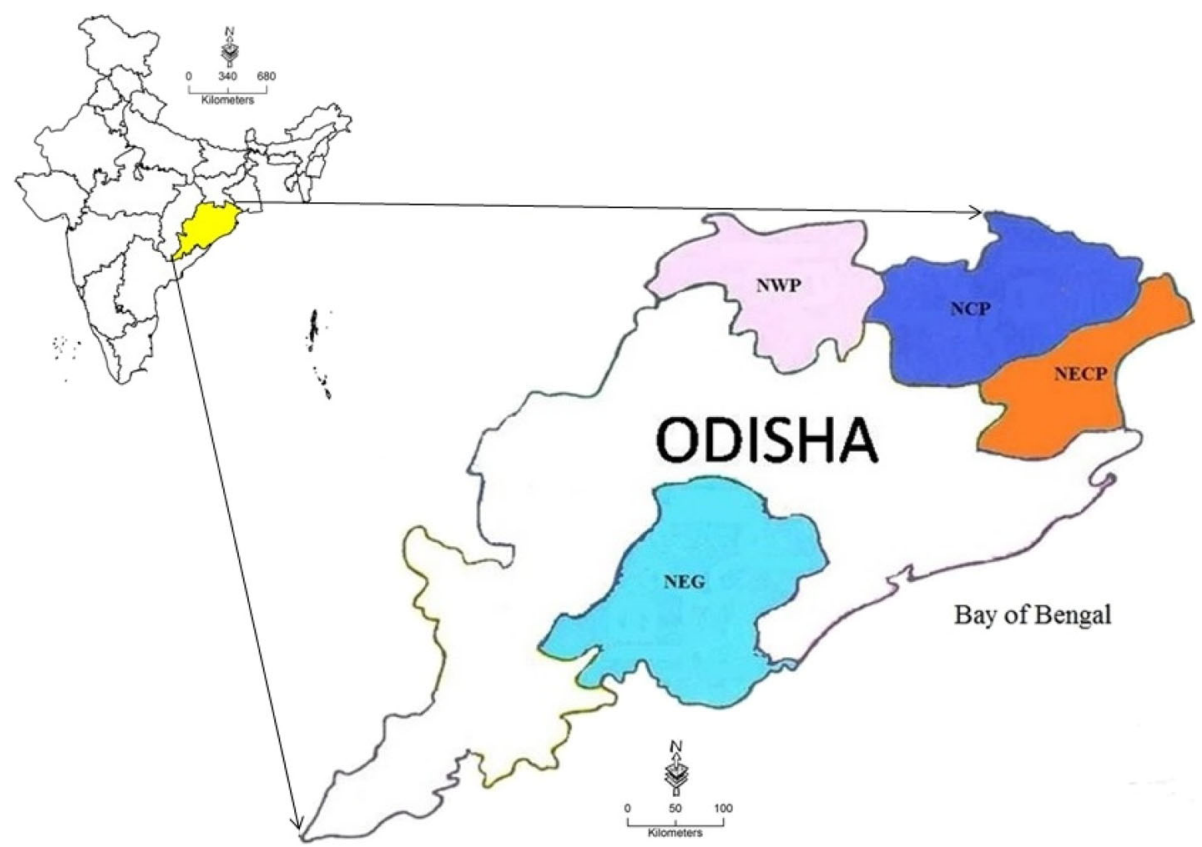

Fig. 1 Map showing study area in eastern India

study units (households) for primary survey. The four ACZs chosen at the first level, which represent distinct physiographical and demographic characteristics, are the north western plateau (NWP, 12,910 $\mathrm{km}^{2}$ ), the north central plateau $\left(\mathrm{NCP}, 17,260 \mathrm{~km}^{2}\right)$, the north eastern coastal plain (NECP, $8840 \mathrm{~km}^{2}$ ), and the north eastern ghat (NEG, 23,050 $\mathrm{km}^{2}$ ). Among all of these zones, NEG represents the lowest level of agro-ecological intensification and is a low productivity area, and NWP is a high productivity area. Further, one district from each ACZ, two blocks from each district, one gram panchayat from each block, and one village from each gram panchayat were selected randomly. Four rice farm fields from each village, comprising 16 rice farms in total from each ACZ, were chosen randomly. Three replicated soil samples were collected from a single farm field; thus a total of 12 soil samples from each village and 48 samples from each ACZ were collected and transported to the

Table 1 Physiography, climate, broad soil group, and cropping pattern of study area

\begin{tabular}{|c|c|c|c|c|c|}
\hline $\begin{array}{l}\text { S. } \\
\text { No. }\end{array}$ & $\begin{array}{l}\text { Agro- } \\
\text { climatic } \\
\text { zone }\end{array}$ & Physiography & Climate & Broad soil group & Major crops \\
\hline 1 & $\begin{array}{l}\text { North } \\
\text { Central } \\
\text { Plateau } \\
\text { (NCP) }\end{array}$ & $\begin{array}{l}\text { Latitude: } 21^{\circ} 1^{\prime} \mathrm{N} \text { to } 22^{\circ} 10^{\prime} \mathrm{N} \text {; } \\
\text { longitude: } 85^{\circ} 11^{\prime} \mathrm{E} \text { to } 86^{\circ} 22^{\prime} \mathrm{E} \\
\text { Forest: } 37.34 \% \text { of total area; } \\
\text { Land form: Valleys and low land, } \\
\text { Mountainous highlands }\end{array}$ & $\begin{array}{l}\text { Hot and moist, sub- } \\
\text { humid, rainfall: } \\
1534 \mathrm{~mm} \text {, temp: } 11.1- \\
36.6^{\circ} \mathrm{C}\end{array}$ & $\begin{array}{l}\text { Lateritic, red and yellow, mixed red } \\
\text { and black }\end{array}$ & $\begin{array}{l}\text { Rice, maize, till, niger, pigeon } \\
\text { pea, etc. }\end{array}$ \\
\hline 2 & $\begin{array}{l}\text { North } \\
\text { Western } \\
\text { Plateau } \\
\text { (NWP) }\end{array}$ & $\begin{array}{l}\text { Latitude: } 20^{\circ} 40^{\prime} \mathrm{N} \text { to } 22^{\circ} 11^{\prime} \mathrm{N} \text {; } \\
\text { longitude: } 82^{\circ} 39^{\prime} \mathrm{E} \text { to } 85^{\circ} 15^{\prime} \mathrm{E} \\
\text { Forest: } 54 \% \text { of total area; land } \\
\text { form: hilly terrain, plateau and } \\
\text { ridges, valley and plains }\end{array}$ & $\begin{array}{l}\text { Hot and moist, sub- } \\
\text { humid, rainfall: } 1600 \\
\text { mm, temp: } 15.0-38.0^{\circ} \mathrm{C}\end{array}$ & $\begin{array}{l}\text { Red, brown forest, red and yellow, } \\
\text { mixed red and black }\end{array}$ & $\begin{array}{l}\text { Rice, gram, pigeon pea, } \\
\text { groundnut, sesame, mustard, } \\
\text { caster, linseed, sugarcane, etc. }\end{array}$ \\
\hline 3 & $\begin{array}{l}\text { North } \\
\text { Eastern } \\
\text { Coastal Plain } \\
\text { (NECP) }\end{array}$ & $\begin{array}{l}\text { Latitude: } 20^{\circ} 48^{\prime} \mathrm{N} \text { to } 21^{\circ} 59^{\prime} \mathrm{N} \text {; } \\
\text { longitude: } 86^{\circ} 16^{\prime} \mathrm{E} \text { to } 87^{\circ} 29^{\prime} \mathrm{E} \\
\text { Forest: } 8.66 \% \text { of total area; Land } \\
\text { form: Costal plains, Hilly terrains }\end{array}$ & $\begin{array}{l}\text { Moist sub-humid, } \\
\text { rainfall: } 1568 \mathrm{~mm} \text {, temp: } \\
\text { 14.8-36.0 }{ }^{\circ} \mathrm{C}\end{array}$ & $\begin{array}{l}\text { Red, lateritic, deltaic alluvial, } \\
\text { coastal alluvial and saline }\end{array}$ & $\begin{array}{l}\text { Rice, pulses, groundnut, caster, } \\
\text { mustard, linseed, etc. }\end{array}$ \\
\hline 4 & $\begin{array}{l}\text { North } \\
\text { Eastern } \\
\text { Ghats (NEG) }\end{array}$ & $\begin{array}{l}\text { Latitude: } 19^{\circ} 34^{\prime} \mathrm{N} \text { to } 20^{\circ} 36^{\prime} \mathrm{N} \text {; } \\
\text { longitude: } 88^{\circ} 34^{\prime} \mathrm{E} \text { to } 84^{\circ} 34^{\prime} \mathrm{E} \\
\text { Forest: } 71.19 \% \text { of total area; } \\
\text { Land form: Hilly terrain with } \\
\text { narrow valleys }\end{array}$ & $\begin{array}{l}\text { Hot and moist, sub- } \\
\text { humid, rainfall: } \\
1597 \text { mm, temp: } 10.4- \\
37.0^{\circ} \mathrm{C}\end{array}$ & $\begin{array}{l}\text { Brown forest, lateritic alluvial, red, } \\
\text { mixed red and black }\end{array}$ & Rice, mustard, maize, niger, etc \\
\hline
\end{tabular}


laboratory for processing and analysis. After collection, soil was allowed to shade dry and was processed (grinding and sieving) for chemical analysis. Information about cropping practices was collected from the land owners through detailed interviews at the time of sampling from the field, using a structured questionnaire. Other basic information like land type, details of crop production and practices, irrigation, marketing, etc. were also collected by face-to-face interviews with selected respondents.

\section{Assessment of ecosystem services}

Rice ecosystem services, including regulating services (biocontrol of pests, carbon flow, soil erosion, nitrogen fixation), provisioning services (food and by-products), and supporting services (soil fertility, hydrological flow, nutrient cycling, and soil formation) were considered for the assessment. Several authors have proposed numerous concepts and classifications of ES that leads to large differences in interpretation of biophysical structures, ecological functions, services, and benefits (Landers and Nahlik 2013; Mononen et al. 2016; Spangenberg et al. 2014; UK 2011; TEEB 2010; La Notte et al. 2017). Such differences make it difficult to differentiate between ecosystem functions and services. In order to avoid double counting, some ES have been kept under ecosystem function (Haines-Young and Potschin 2010; La Notte et al. 2017). However, since many ES have both direct and indirect benefits, categorizing them under ecosystem functions may lead to improper valuation and misuse of those ES. The values of ES such as nitrogen fixation, soil fertility and nutrient cycle, etc., through their direct effects, have been reflected in provisioning service valuation, their indirect effect such as maintaining soil fertility in perpetuity for future generations, and reduction of GHG emissions during the process of production to application of these nutrients in the form of chemical fertilizers, also have some value and need to be accounted for (Spangenberg and Settele 2010). Hence, we have assigned value to these services. Rice holds a great cultural significance to the country like India and more so for Odisha. It is regarded as symbol of prosperity, auspiciousness, and key ingredient in rites and rituals during the ceremonies that signifies transition period in an individual's life and personality development. Previous studies have established relationships among cultural services and rice cultivation, but methods to convert these services to monetary values are rare in the literature. In this study, we did not consider the economic values of cultural services, or those related to the maintenance of biodiversity as well as gas regulation, due to the lack of appropriate data, and lack of an appropriate valuation methodology. Consequently, the total value of ES from rice fields could be higher than the values estimated in this study.

The ES assessment for rice farms followed the method described by Sandhu et al. (2008), which summed the individual ES values. The value of each ES was measured and presented in US dollars (RBI 2017). The components of ES measured are food $\left(\mathrm{ES}_{1}\right)$, by-products $\left(\mathrm{ES}_{2}\right)$, biological control of pests $\left(\mathrm{ES}_{3}\right)$, soil formation $\left(\mathrm{ES}_{4}\right)$, mineralization of plant nutrients $\left(\mathrm{ES}_{5}\right)$, carbon flow $\left(E_{6}\right)$, nitrogen fixation $\left(\mathrm{ES}_{7}\right)$, soil fertility $\left(\mathrm{ES}_{8}\right)$, hydrological flow $\left(\mathrm{ES}_{9}\right)$, and soil erosion $\left(\mathrm{ES}_{10}\right)$. Total ES values were estimated using the following equation:

$$
\mathrm{ES}_{\mathrm{T}}=\sum \mathrm{ES}_{\mathrm{M}}+\sum \mathrm{ES}_{\mathrm{NM}}
$$

Where $\mathrm{ES}_{\mathrm{T}}=$ total $\mathrm{ES}$ value, $\mathrm{ES}_{\mathrm{M}}=$ marketed (tangible) $\mathrm{ES}$ values, and $\mathrm{ES}_{\mathrm{NM}}=$ non-marketed (non-tangible) ES values.

The marketed value of ES comprised the sum of the economic value of products (grains) and by-products (rice straw) produced (Eq. 2), which are traded by farmers directly in the market. The remainder of the services are categorized as non-marketed ES values (Eq. 3) (McTaggart et al. 2003; Sandhu et al. 2008).

$$
\begin{aligned}
& \sum \mathrm{ES}_{\mathrm{M}}=\mathrm{ES}_{1}+\mathrm{ES}_{2} \\
& \sum \mathrm{ES}_{\mathrm{NM}}=\sum \mathrm{ES}_{3-10}
\end{aligned}
$$

\section{Food and by-products}

The ES of food produced from rice farming system was calculated by multiplying the minimum support prices (MSP for the year of 2016-2017) with whole farm produce. MSP is fixed by the government of India to procure the food grains from farmers (Table 2). Likewise, the quantity of by-products produced (rice straw) from rice crops was calculated on the basis of 1.5 times of crop grain yield (Johnson et al. 2006; Sandhu et al. 2008). The economic value was then calculated using the farm gate prices of straw bales at local markets, i.e., US\$ $15 \mathrm{t}^{-1}$ of straw.

\section{Biological control of pests}

Rice insect pests managed by predators and parasitoids were assessed by using real pests and "prey surrogates," used to define a "predation rate" (Root 1967). For calculating predation rate of rice ecosystems, the removal of "prey" types in that particular field was assessed by counting the number of bio-control agents present in the fields (Mala et al. 2009; Shepard et al. 1987; Gurr et al. 2004; Sandhu et al. 2005). The bio-control agents and insect pests were sampled by a sweep net sampling method (Stubbs and Chandler 1978). The economic threshold level of insect-pests (ETL, the farmers are advised to apply 
Table 2 Reference table of rice eco-system services

\begin{tabular}{|c|c|c|c|c|}
\hline Services & $\begin{array}{l}\text { Methodology of } \\
\text { service }\end{array}$ & Conversion factor & Economic value & Reference \\
\hline Food & $\begin{array}{l}\text { 1st crop-rice, 2nd } \\
\text { crop—rice, green } \\
\text { gram, black gram, } \\
\text { groundnut, turmeric }\end{array}$ & Whole farm produce in quintals & MSP of crops & http://eands.dacnet.nic.in/MSP.htm \\
\hline By-products & Rice straw & 1.5 times of grain & US\$ $0.0155 \mathrm{~kg}^{-1}$ & Farm gate price \\
\hline $\begin{array}{l}\text { Biocontrol } \\
\text { of pest }\end{array}$ & $\begin{array}{l}\text { Economic threshold } \\
\text { level (ETL) }\end{array}$ & $\begin{array}{l}\text { Market cost of recommended } \\
\text { dose of pesticide at ETL level }\end{array}$ & $\begin{array}{l}1 \text { Spider }=\text { US\$0.038, } 1 \\
\text { Miridbug = US\$0.008, } 1 \\
\text { Ladybird beetle }= \\
\text { US\$0.06, } 1 \text { Ground } \\
\text { beetle = US\$ } 0.0043\end{array}$ & $\begin{array}{l}\text { Mala et al. 2009; Shepard et al. (IRRI) 1987; Gurr et } \\
\text { al. 2004; Sandhu et al. } 2005\end{array}$ \\
\hline Soil formation & $\begin{array}{l}\text { Earthworms and } \\
\text { Dung beetle }\end{array}$ & $\begin{array}{l}1 \text { tonne of earthworms forms } 1 \\
\text { tonne of soil ha } \mathrm{ha}^{-1} \mathrm{yr}^{-1} ; 2 \mathrm{~g} \text { soil } \\
\text { accumulated per gram of dung } \\
\text { beetle (dry wt basis) }\end{array}$ & $\begin{array}{l}\text { Top-soil value is US\$ } \\
2093 \mathrm{ha}^{-1}\end{array}$ & $\begin{array}{l}\text { Herrick et al. 1996; Sandhu et al. 2008, } \\
\text { Kathuria } 2015\end{array}$ \\
\hline $\begin{array}{l}\text { Mineralization } \\
\text { of plant } \\
\text { nutrients }\end{array}$ & $\begin{array}{l}\text { Assessment of soil } \mathrm{N} \\
\text { mineralization }\end{array}$ & Total $\mathrm{N}=77.78 \%$ of $\mathrm{NH}_{4}$ & $\begin{array}{l}\text { Equivalent price of } \mathrm{N}= \\
\text { US\$ } 0.082 \mathrm{~kg}^{-1}\end{array}$ & Shahid et al. 2017 \\
\hline Carbon flow & $\begin{array}{l}\text { Difference of only } \\
\text { change of } C \text { and } C \\
\text { emission }\end{array}$ & $\begin{array}{l}\text { Carbon accumulation is } 40 \% \text { of } \\
\text { total biomass incorporated in } \\
\text { field, Percentage left over C of } \\
\text { the applied amount from } \\
\text { organic amendments and crop } \\
\text { residues is } 28.8 \% \text { in rice field }\end{array}$ & $\begin{array}{l}\text { CER (Carbon Emission } \\
\text { Reduction) is about } \\
\text { US\$ } 21.71\end{array}$ & $\begin{array}{l}\text { Sandhu et al. 2008; Johnson et al. 2006; } \\
\text { Bhola et al. 2014; Mandal et al. } 2008\end{array}$ \\
\hline $\begin{array}{l}\text { Nitrogen } \\
\text { fixation }\end{array}$ & $\begin{array}{l}\text { Rice-19 } \mathrm{kg} \mathrm{N} \mathrm{ha}^{-1} \\
\text { crop }^{-1} \text {; Green gram } \\
- \\
140 \mathrm{~kg}^{-1} \mathrm{ha}^{-1} \text { year }^{-1}\end{array}$ & & $\begin{array}{l}\text { Equivalent price of } \mathrm{N}= \\
\text { US\$ } 0.082 \mathrm{~kg}^{-1}\end{array}$ & Franco et al. 2000; Roger et al. 1992 \\
\hline Soil fertility & $\begin{array}{l}\text { Nutrient (NPK) } \\
\text { uptake from soil(Net } \\
\text { soil contribution) }\end{array}$ & $\begin{array}{l}\text { NUE }=34 \% ; P U E=25 \% ; \text { KUE }= \\
60 \% \text { for rice }\end{array}$ & $\begin{array}{l}\text { Market price of } \\
\text { fertilizers }\end{array}$ & $\begin{array}{l}\text { Roy et al. 2006; Ravichandran and } \\
\text { Sriramachandrasekharan 2011; Lakshmi et al. 2012; } \\
\text { Vinod and Heuer } 2012\end{array}$ \\
\hline $\begin{array}{l}\text { Hydrological } \\
\text { flow }\end{array}$ & $\begin{array}{l}\text { Rain and irrigation } \\
\text { water recharge }\end{array}$ & $\begin{array}{l}\text { About } 45 \% \text { of total rainfall and } \\
\text { irrigation as recharge to } \\
\text { groundwater }\end{array}$ & US\$ 1.5 per $1000 \mathrm{~m}^{3}$ & $\begin{array}{l}\text { Water charging in irrigated agriculture (FAO 2001); } \\
\text { Tripathi } 2016\end{array}$ \\
\hline Erosion & $\begin{array}{l}\text { District level data of } \\
\text { soil erosion }\end{array}$ & $\begin{array}{l}\text { Sediment delivery ratio } \\
(\mathrm{SDR})=0.3\end{array}$ & $\begin{array}{l}\text { Top soil value as US\$ } \\
2093 \mathrm{ha}^{-1}\end{array}$ & $\begin{array}{l}\text { http://www.dowrorissa.gov.in/DIP/DIPIndex.htm, } \\
\text { Sreenivasalu. } 2012\end{array}$ \\
\hline
\end{tabular}

pesticides only when the pest population reaches above this level) was used to calculate insect-pest infestation per ha at ETL level. The recommended dose of pesticides against these pests were multiplied by the market price, along with the application cost to get the total cost of pest control per ha, which was subsequently used to calculate the cost involved for controlling the respective single insect-pests. Predation rate was calculated from the removal of prey by effective feeding capacity of each predator in their life cycle (Shepard et al. 1987). Their corresponding predation rate was used to calculate the number of pests removed. The value of biological control of insect-pest was calculated by multiplying the number of pests removed by the cost involved in controlling single pests (Table 2).

\section{Soil formation}

The ecosystem value due to soil formation was assessed on the basis of earthworm and dung beetles population in the rice fields (Table 2). The number of earthworms and dung beetles were observed by the Tullgren funnel method (Southwood 1978). The mean biomass of an earthworm is $0.2 \mathrm{~g}$ (Fraser et al. 1996), and $1 \mathrm{t}$ of earthworms forms $1 \mathrm{t}$ of soil ha ${ }^{-1}$ year $^{-1}$ (Pimentel et al. 1995; Sandhu et al. 2008). It was reported that $2 \mathrm{~g}$ of soil was formed per gram of dung beetle on a dry weight basis (Herrick and Lal 1996). The economic value of soil formation was estimated by multiplying the top soil value with the amount of soil formed annually. The economic value of one foot $(\sim 30 \mathrm{~cm})$ of top-soil in India was reported as US\$ $2093 \mathrm{ha}^{-1}$ (Kathuria 2015) and was used in this study for ES evaluation.

\section{Mineralization of plant nutrients}

The economic value of mineralization of plant nutrients was calculated using data on mineralization of soil nitrogen obtained from the soil samples. Nitrogen mineralization $\left(\mathrm{N}_{\min }\right)$ was determined by incubating soil 
for 1 month. To measure mineral $\mathrm{N}\left(\mathrm{NH}_{4}-\mathrm{N}\right)$ of the incubated soil, extraction with $2 \mathrm{M} \mathrm{KCl}$ (Keeney and Nelson 1982) was done followed by colorimetric determination using the indophenol blue method based on the Berthelot reaction. Net mineralized $\mathrm{N}$ was calculated and cumulative $\mathrm{N}_{\min }$ was determined (Shahid et al., 2017) and converted to annual mineralization of nitrogen (Table 2). Total amount of nitrogen mineralized was valued at the equivalent price $\mathrm{kg}$ of $\mathrm{N}$ fertilizer (US\$ $0.0824 \mathrm{~kg}^{-1}$ ), giving the economic value of nitrogen mineralization.

\section{Carbon flows and greenhouse gas emissions}

Carbon flow was estimated considering the total carbon input in to the soil in the form of stubble, roots, and rhizodiposition, and emission of carbon dioxide $\left(\mathrm{CO}_{2}\right)$, methane $\left(\mathrm{CH}_{4}\right)$, and nitrous oxide $\left(\mathrm{N}_{2} \mathrm{O}\right)$ in the form of carbon equivalents. The proportion of stubble, roots, and rhizodiposition were taken as $2.5 \%, 19 \%$, and $15 \%$ of the total biomass production, respectively from rice field (Mandal et al. 2008). The carbon content of the residues added to the soil was taken as 40\% (Johnson et al. 2006). Carbon left over in soil was then estimated as $28.8 \%$ of total added carbon in soil (Mandal et al. 2008). $\mathrm{CO}_{2}, \mathrm{CH}_{4}$, and $\mathrm{N}_{2} \mathrm{O}$ are the main greenhouse gas (GHGs) emitted from rice fields. Due to their potential role in the global warming, GHGs from rice field do a disservice to the ecosystem. A partial life cycle assessment (LCA) method (Hillier et al. 2009; Dubey and Lal 2009; Yan et al. 2015) was used to quantify the carbon emissions associated with rice cultivation, considering direct and indirect GHG emissions within the farm gate (from sowing to harvest). The direct GHG emissions was estimated from application of nitrogen $(\mathrm{N})$ fertilizer (as $\mathrm{N}_{2} \mathrm{O}$ ), $\mathrm{CH}_{4}$ emissions (Yan et al. 2003; IPCC 2006), from manure application Zou et al. 2007) and the indirect emissions were estimated by adopting the reported value from agrochemical manufacture processes (Soni et al. 2013; Yan et al. 2015).

The economic value of carbon flow (carbon sequestration-carbon emission) in rice fields is estimated based on the value of one carbon emission reduction (CER) or carbon credit, which is about US\$21.7 $\mathrm{t}^{-1}$ of carbon (Bhola and Malhotra 2014).

\section{Nitrogen fixation}

Nitrogen fixation by beneficial microorganisms for rice was estimated based on the value given by (Roger and Ladha 1992). In addition, a quantity of nitrogen is fixed by legume crops (Franco and Balieiro 2000), which is also included in the calculation, wherever legumes were grown followed by a rice crop (Table 2). The economic value of nitrogen fixed in such land was estimated by the amount of nitrogen fixed per hectare, which was then valued at the unit price of urea (US\$ $0.0824 \mathrm{~kg}^{-1}$ ) in rice-based ecosystems.

\section{Soil fertility}

The soil fertility service of rice fields was estimated by the soil's contribution to available forms of nitrogen, phosphorus, potash, sulfur, and other micronutrients in representative soils. We estimated the nutrient uptake from soil for unit of economic produce (Roy et al. 2006). The contribution of nutrients from fertilizer was estimated from standard nutrient use efficiency for rice, i.e., $\mathrm{N}$ (34\%), $\quad \mathrm{P}_{2} \mathrm{O}_{5}$ (25\%), $\quad \mathrm{K}_{2} \mathrm{O} \quad(60 \%)$ (Ravichandran and Sriramachandrasekharan 2011; Lakshmi et al. 2012; Vinod and Heuer 2012) of the region (Table 2). Uptake by plants from soil was calculated by deducting fertilizer nutrient contribution from total uptake. These soil nutrients were valued at the unit price of respective local fertilizers.

\section{Hydrological flow}

The rice is cultivated in bunded fields that reduces the runoff and increases the residence time for percolation. We calculated the ES value from bunded rice fields through ground water recharge by taking $45 \%$ of total rainfall and irrigation as recharge to groundwater (Tripathi 2016). The recharged ground water can be extracted and used for irrigation. These irrigation water otherwise would have been purchased. This is one of the most important services provided by the rice cultivation system. Thus economic value of recharged ground water was calculated at a purchase price of irrigation water, i.e., US\$ 1.5 per $1000 \mathrm{~m}^{3}$ water (FAO 2004).

\section{Soil erosion}

Soil erosion does a disservice to the ecosystem and needs to be deducted from the total ES values. Soil erosion was calculated from the reference data given by the Department of Water Resources (2015) and the soil erosion map of the state (ICAR/DARE Annual Report, 2006-2007). However, rice is cultivated in a bunded system in this region. The bund height ranges from 0.50 to $0.75 \mathrm{~m}$. Since the average size of field is less than $0.1 \mathrm{ha}$, the sediment delivery ratio (SDR) is assumed to be 0.3 (Sreenivasalu 2012), which is ultimately lost from the rice field. This factor is multiplied by the reference soil erosion data of the region to get the actual soil loss. This value is then multiplied with the value of top soil, i.e., US\$ $2093 \mathrm{ha}^{-1}$ of soil (Kathuria 2015) to calculate the economic value of soil loss.

\section{Farm income and land holding identification/classification}

Household farm income covers the value of the main and allied crop commodities produced on the farm, 
valued at local market prices in a year. Using a villagewise list of households available from the Sarpanch (Village head), 25 households were chosen, considering representation of different land-holding groups (Singh and Singh 2016) from each sampled village. Thus, a total of 400 households from four ACZs were selected. Respondents were asked to specify in detail all farm outputs, and prices for the different commodity in the local market over the last 12-month period preceding to the survey, as per the standard methodology adopted for the NSSO survey (NSSO 2013). Household farm income was determined by multiplying the quantity of total outputs produced with the average price of the respective commodities in the previous 12 months.

\section{PCA and cluster analysis}

Spatial trade-offs and synergies among specific ecosystem service values in rice fields were examined by using a principal component analysis (PCA) and cluster analysis using SAS software (SAS 2008). In order to do so, spatial data for the specific ecosystem services were used as active variables and the spatial data for different zones [16 variables including four from each ACZ, i.e., NECP (Dhuliguda-BD, Baniamari-BB, Siadimal-BS, Jamundia-BJ), NWP (Kusarimunda-SK, Badbahal-SB, Larbanga-SL, Singhpali-SS), NCP (Sirispal-KS, Baliaguda-KB, Talagaon-KT, DeogaonKD), and NEG (Kalinga-PK, Gatamaha-PG, MakapataPMK, Malebadi-PML)] as supplementary variables. Hierarchical cluster analysis (HCA) was conducted to identify possible clusters of individuals sharing similar patterns.

\section{Economic Gap analysis of ES}

The gap of ecosystem service values of rice farming, and actual farm income from rice farms for different landholding groups, was estimated by subtracting perha farm income accrued from per-ha ES value estimated. The maximum and minimum gap was calculated by subtracting per-ha farmer income from perha total ecosystem service value, and marketed ES values, respectively. The maximum gap signifies the difference between actual farm income and the income generated by the farm through its contributions toward marketed and non-marketed ecosystem services. However, the minimum gap, which can be termed as the marketed gap, corresponds to the difference between the actual income from the farm and the income through marketed ecosystem services, which is calculated based on the minimum support price (MSP) of the crops. Hence, this gap represents the difference between the MSP of crops and the actual sale price at the farm gate.

\section{Results}

Food and by-products as marketed ES

The marketed ecosystem services which include both food and by-products were calculated based on the MSP for rice (US\$ $228 \mathrm{t}^{-1}$ ) and local market values for other crops, respectively in four ACZs of eastern India (Table 3). Among four ACZs, NWP had the highest (US\$ $1119 \mathrm{ha}^{-1}$ year $^{-1}$ ) and NECP the lowest (US\$ $981 \mathrm{ha}^{-1}$ year $^{-1}$ ) food ES values (Table 3). Different rice-based cropping systems, such as rice-rice, rice-oil seed, or rice-pulses had a higher value compared to rice mono crops. Similarly, rice-rice cropping patterns had the highest raw material value in NWP (US\$ $114 \mathrm{ha}^{-1}$ year ${ }^{-1}$ ) with a mean value of US\$ 72 $\mathrm{ha}^{-1}$ year $^{-1}$. The total marketed value for food and by-products ranged from US\$ $1052 \mathrm{ha}^{-1}$ year $^{-1}$ (NECP) to US\$ $1234 \mathrm{ha}^{-1}$ year $^{-1}$ (NWP) with a mean value of US\$ $1122 \mathrm{ha}^{-1}$ year $^{-1}$.

\section{Biological control of pests}

There is a wide variation in the ES value of biological control of pest services across the four ACZs with an average value of US\$ $1.6 \mathrm{ha}^{-1}$ year $^{-1}$ per ha of land. NEG showed highest values of bio-control services (US\$ $2.9 \mathrm{ha}^{-1}$ year $^{-1}$ ) and NECP showed the lowest value (US\$ $0.2 \mathrm{ha}^{-1}$ year $^{-1}$ ) (Table 3).

\section{Soil formation}

The economic value of the soil formation ranged from US\$ $7 \times 10^{-8} \mathrm{ha}^{-1}$ year $^{-1}$ at NWP to US\$ $0.5 \times$ $10^{-8} \mathrm{ha}^{-1}$ year $^{-1}$ at NEG with the mean value of US\$ $2.8 \times 10^{-8} \mathrm{ha}^{-1}$ year $^{-1}$ (Table 3).

\section{Mineralization of plant nutrients}

The highest ES value due to mineralization of plant nutrients was observed in NECP (US\$ $111 \mathrm{ha}^{-1}$ year $^{-1}$ ), whereas NWP had the lowest value (US\$ $64 \mathrm{ha}^{-1}$ year $^{-1}$ ). The mean ES due to mineralization of plant nutrients was evaluated to be US\$ $80 \mathrm{ha}^{-1}$ year $^{-1}$ in four different ACZs (Table 3).

\section{Carbon flow}

On the basis of carbon flow, i.e., net carbon addition and emissions of GHGs expressed as net carbon equivalent $\left(\mathrm{t} \mathrm{ha}{ }^{-1}\right)$, the economic value was assessed by the trading value of one carbon credit of about US\$ $21.7 \mathrm{ha}^{-1}$ (Bhola and Malhotra, 2014). It was observed that the effect of carbon emissions (disservice) was highly variable, and these were deducted from net $C$ change in the rice field to estimate the economic value of the carbon flow. In rice-rice ecosystems, the highest value of carbon flow (US\$ $3.6 \mathrm{ha}^{-1}$ year $^{-1}$ ) was observed in the NWP zone and the lowest value in the NECP zone (US\$ -0.8 $\mathrm{ha}^{-1}$ year $^{-1}$ ) (Table 3). The average value of ES through 
Table 3 Values of ecosystem service (in $\$ \mathrm{ha}^{-1}$ year ${ }^{-1}$ ) generated in rice cultivated field under different agro-climatic zones

\begin{tabular}{|c|c|c|c|c|c|}
\hline Ecosystem services & NCPa & NWP & NECP & NEG & Mean \\
\hline Food & $1040 \pm 97$ & $1119 \pm 186$ & $981 \pm 90$ & $1059 \pm 112$ & 1050 \\
\hline By products & $67 \pm 8$ & $114 \pm 19$ & $71 \pm 4$ & $37 \pm 6$ & 72 \\
\hline Market value of ES & 1107 & 1234 & 1052 & 1096 & 1122 \\
\hline Biocontrol of pest & $1.2 \pm 0.3$ & $2 \pm 0.3$ & $0.2 \pm 0.1$ & $2.9 \pm 0.4$ & 1.6 \\
\hline Soil formation $\left(/ 10^{8}\right)$ & $2.3 \pm 0$ & $7 \pm 0$ & $1.4 \pm 0$ & $0.5 \pm 0$ & 2.8 \\
\hline Mineralisation of plant nutrients & $76 \pm 3$ & $64 \pm 2$ & $111 \pm 4$ & $68 \pm 2$ & 80 \\
\hline Carbon flow & $-0.5 \pm 0.6$ & $3.6 \pm 1.1$ & $-0.8 \pm 0.3$ & $-0.3 \pm 0.3$ & 0.5 \\
\hline Nitrogen fixation & $10 \pm 0.9$ & $2 \pm 0.2$ & $9 \pm 1.3$ & $1 \pm 0$ & 5.5 \\
\hline Soil fertility & $487 \pm 22$ & $101 \pm 16$ & $371 \pm 62$ & $64 \pm 9$ & 256 \\
\hline Hydrological flow & $11 \pm 0.2$ & $12 \pm 0.1$ & $12 \pm 0.2$ & $11 \pm 0$ & 11 \\
\hline Soil erosion & $-3.7 \pm 0.8$ & $-2.1 \pm 0$ & $-4.2 \pm 0$ & $-4.2 \pm 0.1$ & -4 \\
\hline Non-market value of ES & 581 & 183 & 498 & 142 & 351 \\
\hline Total economic value of ES & 1688 & 1416 & 1550 & 1238 & 1473 \\
\hline
\end{tabular}

Negative sign for disservice; values [mean \pm standard error $(\mathrm{SE})]$

${ }^{a}$ NCP North Central Plateau, NWP North Western Plateau, NECP North Eastern Coastal Plain, NEG North Eastern Ghats

carbon flow was calculated as US\$ $0.5 \mathrm{ha}^{-1}$ year $^{-1}$ for all ACZs.

\section{Nitrogen fixation}

The economic value of nitrogen fixed in arable rice land in eastern India was calculated on the basis of literature, and was reported as the mean nitrogen fixation service, i.e., US\$ 5.5 in rice ecosystem per hectare, annually. However, NCP, with its dominant area under rice-legume cropping systems, had the highest value, i.e., US\$ $10 \mathrm{ha}^{-1}$ year $^{-1}$ and NEG (mostly rice-fallow) the lowest value for the nitrogen fixation ES (Table 3).

\section{Soil fertility}

Wide differences in ES values due to soil fertility status were observed among different ACZs, ranging from US\$ $64 \mathrm{ha}^{-1}$ year $^{-1}$ to US\$ $487 \mathrm{ha}^{-1}$ year $^{-1}$ (Table 3). Ricepulse systems had the highest value for fertility status among all the rice-based systems. In NCP, ground nut is grown as a rabi crop, and had the highest value (US\$ $638 \mathrm{ha}^{-1}$ year $^{-1}$ ), with a mean value of US\$ 256 $\mathrm{ha}^{-1}$ year $^{-1}$ (Table 3) in four ACZs.

\section{Hydrological flow}

Based on the topographic situation and the amount of water precipitation, the hydrological flow in these zones varies greatly with time. The mean ES value was recorded as US\$ $11.4 \mathrm{ha}^{-1}$ year $^{-1}$ due to recharge of ground water in four ACZs throughout the year. Among the four ACZs, the NWP and NECP zone had the highest value (US\$ $12 \mathrm{ha}^{-1}$ year $^{-1}$ ) and the NCP and NEG zone had the lowest value (US\$ $11 \mathrm{ha}^{-1}$ year $^{-1}$ ) in rice farming systems (Table 3 ).

\section{Soil erosion}

On the basis of soil erosion data from all four ACZs collected from the Department of Water Resources and state erosion map, the net economic values of soil loss in all the study regions were calculated. Among all four ACZs, the soil erosion ES value varied from -4.2 to $-2.1 \mathrm{ha}^{-1}$ year $^{-1}$. However, NEG and NECP had the greatest negative value (as it is a disservice) and NWP had the lowest negative value of the soil erosion service (Table 3 ).

\section{Farm income and land holding classes}

Average farm income from rice farm ranged from US\$ $523 \mathrm{ha}^{-1}$ year $^{-1}$ (NEG) to US\$ $795 \mathrm{ha}^{-1}$ year $^{-1}$ (NECP) with mean farm income of US\$ $672 \mathrm{ha}^{-1}$ year $^{-1}$ in all the four ACZs. Marginal farmers received higher farm income (US\$ 642-662 $\mathrm{ha}^{-1}$ year $^{-1}$ ) than large farmers (US\$ 404$731 \mathrm{ha}^{-1}$ year $^{-1}$ ) per unit land, in all the ACZs except NWP zone, where the trend was the opposite (Table 4).

\section{Economic gap analysis}

The total economic gap (maximum gap), as estimated by subtracting the average annual farm income from total

Table 4 Agricultural income of different land-holding classes in US\$ ha ${ }^{-1}$ year $^{-1}$

\begin{tabular}{lllll}
\hline Land holding groups & NCP $^{\text {a }}$ & NWP & NECP & NEG \\
\hline Marginal (<0.4 ha) & 642 & 662 & 841 & 643 \\
Small (<0.4-1 ha) & 643 & 684 & 792 & 609 \\
Medium (<1-2 ha) & 629 & 768 & 815 & 438 \\
Large ( $>$ 2 ha) & 585 & 870 & 731 & 404 \\
Mean & 625 & 746 & 795 & 523 \\
\hline
\end{tabular}

${ }^{\mathrm{a} N C P}$ North Central Plateau, NWP North Western Plateau, NECP North Eastern Coastal Plain, NEG North Eastern Ghat 
ES value per ha of rice field was highest for NCP (US\$ $1063 \mathrm{ha}^{-1}$ year $^{-1}$ ) and lowest for NWP (US\$ 670 $\mathrm{ha}^{-1}$ year $^{-1}$ ) with a mean of US\$ $801 \mathrm{ha}^{-1}$ year $^{-1}$ in all the four ACZs. Similarly, the marketed gap (minimum gap) as calculated by subtracting the annual farm income from marketed ES value per ha of rice field was highest for the NEG zone (US\$ $573 \mathrm{ha}^{-1} \mathrm{year}^{-1}$ ) and lowest for the NECP zone (US\$ $257 \mathrm{ha}^{-1} \mathrm{year}^{-1}$ ). The mean economic gap of marketed ES (marketed gap) was US\$ $450 \mathrm{ha}^{-1}$ year $^{-1}$ for all four ACZs (Table 5).

\section{PCA and cluster analysis}

We included all the ten parameters of ecosystem services (food, by products, biocontrol of pests, soil formation, mineralization of plant nutrients, carbon flow, nitrogen fixation, soil fertility, hydrological flow, and soil erosion) and 16 locations in all the four ACZs for PCA analysis. The analysis showed that the factor I (which accounts for $37.7 \%$ of the variance) was explained by the food, by-products, carbon flow, and hydrological flow of the rice ecosystem. The factor II (which accounts for $35.1 \%$ of the variance) was explained by biocontrol of pest, carbon flow services. Thus, the first two factors accounted around $72.8 \%$ of the variance in ecosystem services of the study area. All individuals were put into the coordinate system constituting the factor map shown in Fig. 2. Individual data points with similar characteristics are bundled into three separate clusters using HCA (Table 6). Cluster 3 showed the greatest contribution to food and by-products. This group also contributed the highest value for biocontrol of pest, mineralization of plant nutrient, as well as carbon and hydrological flow to the environment. Cluster 1 showed the lowest total values of ecosystem services in eastern India. Economic value from food, by-products, nitrogen fixation, and soil fertility status services were lowest for this cluster.

\section{Discussion}

\section{Marketed ES}

Annual economic value of combined marketed and non-marketed ecosystem services from rice fields in four ACZs in eastern India ranged from US\$ 1238 to $1688 \mathrm{ha}^{-1}$ year $^{-1}$ (Table 3). Farmers are directly benefited from marketed ES, i.e., provisioning services, by selling grain and straw (i.e., primary production) in the market. Marketed ES from rice farms of four ACZs ranged from US\$ 1052 to 1234 $\mathrm{ha}^{-1}$ year $^{-1}$ with a mean of US\$ $1122 \mathrm{ha}^{-1}$ year $^{-1}$, which contributes about 66 to $89 \%$ toward the total value of ES from rice fields. The economic value per unit area of primary production constitutes only 11 to $26 \%$ of the integrated economic value per unit area of rice ecosystem services in China (Xiao et al. 2011). The provisioning value of only the wheat component in a ricewheat system was US\$ $1035 \mathrm{ha}^{-1}$ in North India (Pathak et al. 2017). According to (Sandhu et al. 2008) major portion of ES in the intensively cultivated area with cereal, vegetables, and cash crops from arable land of the Canterbury region in New Zealand ranged from US\$ 840 ha $^{-1}$ year $^{-1}$ to US\$ 14,000 ha $^{-1}$ year $^{-1}$, with a mean value of US\$ $3220 \mathrm{ha}^{-1}$ year $^{-1}$. Inclusion of cash crops in the system resulted in higher values of provisioning services.

Though rice is the main cereal crop grown in the eastern part of India, its productivity is still below the country's mean productivity level $\left(2391 \mathrm{~kg} \mathrm{ha}^{-1}\right.$; Government of India (GOI), Ministry of Agriculture, 2016). In most parts of this region, rice is cultivated as a mono crop followed by fallow, and the average consumption of fertilizer for this region (NPK) is $63 \mathrm{~kg} \mathrm{ha}^{-1}$, which is much lower than the national average of $131 \mathrm{~kg} \mathrm{ha}^{-1}$ (GOI 2016). Factors such as frequent flood, drought, and cyclones in the eastern part of the country are responsible for the low productivity in this region (Department of Water Resources 2009). In this study, it was observed that those areas that adopted a double cropping pattern, i.e., rice-rice, rice-oil seed, and rice-pulses produced higher ES values (the NCP, NECP, and NWP zones) than mono-cropping areas (the NEG zone). Crop diversification, better crop management, post-harvest management, and value addition can improve the marketed ES in this region. Growing of pulses in rice-fallow will not only increase the economic value but also maintain the soil health by increasing the fertility status and minimizing soil loss (Singh et al. 2016). Preparation of brown rice, puffed rice, flaked rice, rice crisp, ready-toeat foods, and extruded foods are some options available

Table 5 Comparison of economic gap between total and marketed ES

\begin{tabular}{|c|c|c|c|c|}
\hline$\overline{A C Z s}$ & Total ES & Maximum gap & Marketed ES & Minimum gap (marketed gap) \\
\hline \multicolumn{5}{|c|}{ US\$ ha ${ }^{-1}$ year $^{-1}$} \\
\hline$N C P^{a}$ & 1688 & 1063 & 1107 & 482 \\
\hline NWP & 1416 & 670 & 1234 & 488 \\
\hline NECP & 1550 & 755 & 1052 & 257 \\
\hline NEG & 1238 & 715 & 1096 & 573 \\
\hline Mean & 1473 & 801 & 1122 & 450 \\
\hline
\end{tabular}

${ }^{a}$ NCP North Central Plateau, NWP North Western Plateau, NECP North Eastern Coastal Plain, NEG North Eastern Ghats 


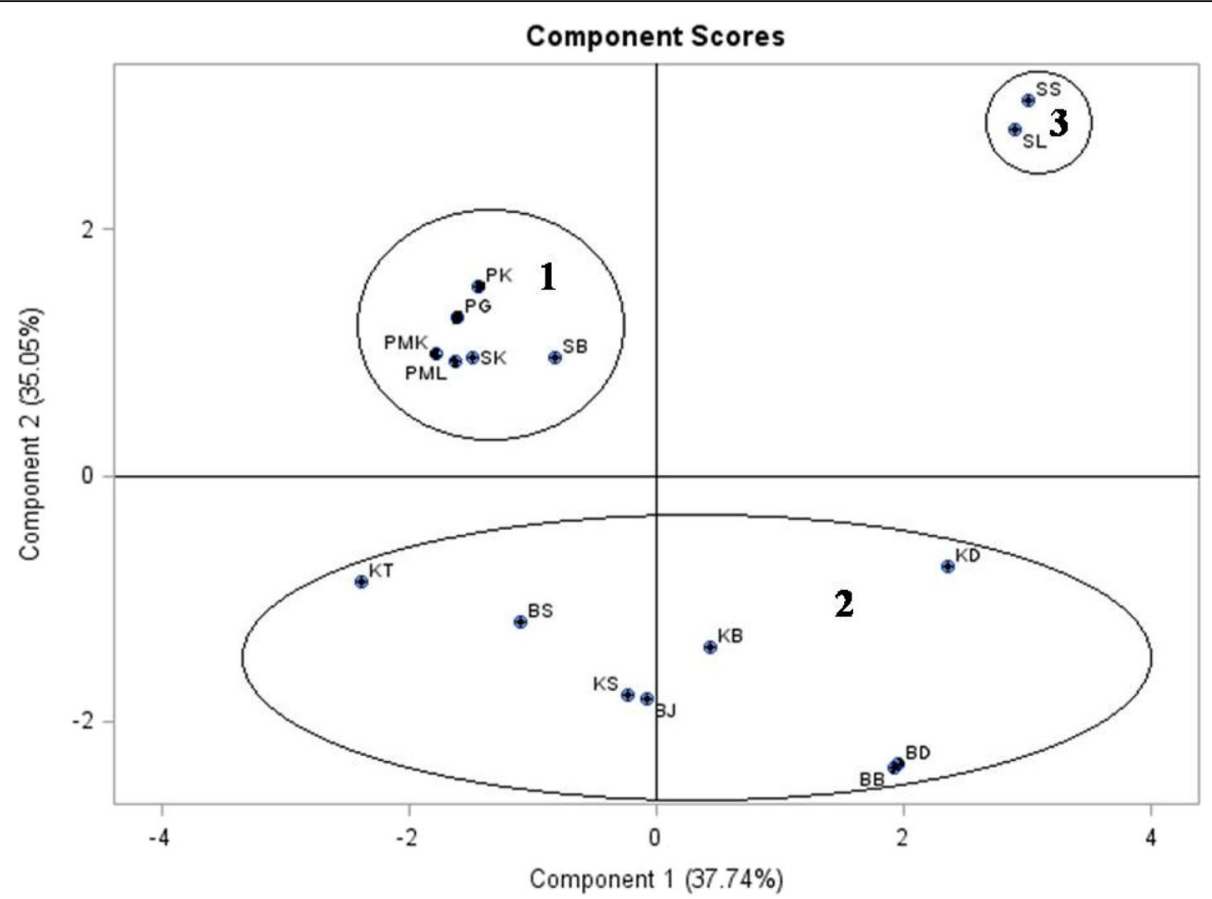

Fig. 2 Factor map for quantitative variables of different agro-climatic zones. [16 locations from four ACZs i.e. NECP (Dhuliguda-BD, Baniamari-BB, Siadimal-BS, Jamundia-BJ), NWP (Kusarimunda-SK, Badbahal-SB, Larbanga-SL, Singhpali-SS), NCP (Sirispal-KS, Baliaguda-KB, Talagaon- KT, DeogaonKD) and NEG (Kalinga-PK, Gatamaha-PG, Makapata-PMK, Malebadi-PML)]

for value addition of rice grain (Singaravadivel 2016). Grain by-products like rice bran (contains $10-23 \%$ bran oil), which are in demand due to their anti-oxidant properties, are another possibility for value addition. Similarly, rice husks can add value, when converted to briquettes and pellets (Ozyuguran et al. 2014).

Using rice straw for mushroom production is another option; about $50-100 \mathrm{~kg}$ of mushrooms can be prepared using $1 \mathrm{t}$ of dried rice straw (Zhang et al. 2002). Rice straw composite products, such as biochar and particle boards, can have great environmental benefits along with higher economic value, and are at least
$20 \%$ cheaper than existing forest wood technology alternatives ( Mantanis et al. 2000). Further, rice straw is not considered as a good animal feed (Singh and Sidhu 2014) due to its high silica content (Drake et al. 2002). Hence, efforts are needed for increasing the digestibility of rice straws as livestock feed, through appropriate breeding strategies (Sarnklong et al. 2010).

\section{Other services as non-marketed ES}

Usually primary production (tangible in nature) is considered for socioeconomic analysis and estimation,

Table 6 Quantitative PCA representatives

\begin{tabular}{|c|c|c|c|c|c|c|c|c|c|c|c|}
\hline Cluster & Food $^{a}$ & $\mathrm{BP}^{\mathrm{b}}$ & $B C P^{* C}$ & $\mathrm{SFO}^{\mathrm{d}}$ & $M N^{e}$ & $\mathrm{CF}^{f}$ & $\mathrm{NF}^{\mathrm{g}}$ & $\mathrm{SF}^{\mathrm{h}}$ & $\mathrm{HF}^{\mathrm{i}}$ & $\mathrm{Er}^{\mathrm{j}}$ & Total ES \\
\hline \multicolumn{12}{|c|}{ US\$ ha ${ }^{-1}$ year $^{-1}$} \\
\hline 1 & 881.2 & 42.7 & 2.4 & 0.0 & 65.0 & -0.2 & 1.4 & 58.5 & 11.1 & -3.5 & 1058.6 \\
\hline 2 & 1010.5 & 69.2 & 0.7 & 0.0 & 93.6 & -0.6 & 9.3 & 429.0 & 11.4 & -3.9 & 1619.2 \\
\hline 3 & 1431.5 & 125.7 & 1.1 & 0.0 & 94.2 & 3.8 & 7.1 & 331.4 & 12.4 & -3.1 & 2004.2 \\
\hline
\end{tabular}

* US\$ ha ${ }^{-1}$ year $^{-1} \times 10^{-8}$

${ }^{\mathrm{a}}$ Food production

${ }^{\mathrm{b}}$ By-products

'Biocontrol of pest

${ }^{\mathrm{d}}$ Soil formation

${ }^{\mathrm{e}}$ Mineralization of plant nutrient

fCarbon flow

${ }^{9}$ Nitrogen fixation

${ }^{\text {h}}$ Soil fertility

'Hydrological flow

jSoil erosion 
neglecting other components of ES (non-marketed ES) that often constitute a significant portion of the total ES (Sandhu et al. 2008). Hence, in this study, various nonmarketed ES such as biocontrol of pests, soil formation, mineralization of plant nutrients, carbon flows, nitrogen fixation, soil fertility, hydrological flows, and soil erosion have been valued and presented.

\section{Biological control of pests}

Predators and parasitoids in rice fields play a vital role in keeping harmful pests under control. In this paper, the NEG zone had the highest value (US\$ 2.9 $\mathrm{ha}^{-1} \mathrm{year}^{-1}$ ) and NECP the lowest (US\$ 0.2 $\mathrm{ha}^{-1}$ year $^{-1}$ ) in terms of bio-control of pests. Predator abundance and diversity varies from one ACZ to another, which contributed to different values from this particular ES. Many studies have found relationships between predator abundance and diversity for effective pest control (Bianchi et al. 2006; Letourneau et al. 2009; Chaplin-Kramer et al. 2011). Higher use of pesticides in farming inhibits the ability of farm land support service such as biocontrol of insect pests (Sandhu et al. 2005). Ensuring the abundance of predators and parasites by limited use of pesticide could enhance the bio-control of pests (Gurr et al. 2004). However, the values are negligible (less than 1\%) compared to the marketed ES.

\section{Soil formation}

The mean economic value of this service was US\$ $2.8 \times$ $10^{-8} \mathrm{ha}^{-1}$ year $^{-1}$ which includes only the activity of earthworms and dung beetles; other drivers of soil formation have not been accounted for in this study. These two soil organisms are responsible for a large part of formation of soil, maintaining the soil structure and fertility (Stockdill 1982; Lee 1985; Edwards 2004). Soil biota provides the soil formation ES (Breemen and Buurman 2002) and grow better in low to medium humid soils than upland dry soils. The lowest soil formation value was seen for the NEG, which is part of the Eastern Ghat range, where dry upland conditions prevailed. The values are negligible compared to the marketed ES.

\section{Mineralization of plant nutrient}

Nitrogen is the main plant nutrient which is available to crops. To estimate the economic value of $\mathrm{N}$, which is available to crops by mineralization process was calculated by direct laboratory estimation of $\mathrm{NH}_{4}$ mineralization of soil collected from field. This was converted to total $\mathrm{N}$ which is $78 \%$ of $\mathrm{NH}_{4}$, and finally converted to market value of nitrogen fertilizer. Sandhu et al. $(2005,2008)$ described the economic value of plant nutrient mineralization which was assessed using bait-lamina probes (Kratz 1998; Torne 1990) in the field and the value varied from US\$ $142 \mathrm{ha}^{-1}$ year $^{-1}$ in conventional fields to US\$ $260 \mathrm{ha}^{-1}$ year ${ }^{-1}$ in organic fields. In this study, the value of ES due to mineralization of nitrogen ranged from US\$ $64 \mathrm{ha}^{-1}$ year $^{-1}$ in NWP to US\$ 111 $\mathrm{ha}^{-1}$ year $^{-1}$ in NECP. Soil microorganisms and invertebrates decompose organic matter to simpler forms (plant available form) (Brady and Weil 2004), which is one of the most important services provided by soil.

\section{Carbon flow}

We calculated the total carbon flow in rice farming systems by accounting the net carbon addition and carbon emission (GHG emission in terms of $t \mathrm{C}$ $\mathrm{ha}^{-1}$ ), which indicates a source and sink behavior of studied ACZs, with an overall sink. Rice, along with other succeeding crops, is a major contributor of GHG emissions to the environment. Rice is usually cultivated in flooded soil and produces methane from anaerobic decomposition in the submerged soils, and nitrous oxide from nitrogen fertilizers (FAO 2005), resulting in much higher GHG emissions than aerobic crops (Pathak et al. 2010).

Improved management practices such as optimized tillage or conservation agriculture, and crop residue management after crop harvest can increase carbon accumulation in soils (Garcia-Torres et al. 2003; Magdoff and Weil 2004). This study, where double cropping was practiced (rice-rice, rice-pulses, etc.), showed large carbon flows compared to mono-cropping areas. The carbon input calculation method used in this study involves uncertainty due to different agro-climatic zones, soil type, management practices such as tillage and water management followed, etc. (detailed uncertainty analysis of all ES is presented in Additional file 1: Table S1); however, the system acts as sink and has been reported in other studies (Nayak et al. 2012; Bhattacharyya et al. 2014; Swain et al. 2016). It is evident from 27-year long-term experiments that there is a depletion of SOC in trans and upper Indo-Gengetic plains (IGP) in N-W India and buildup of SOC in lower IGP (eastern India) under ricewheat systems (Nayak et al. 2012). However, considering all the components of the $\mathrm{C}$ balance including $\mathrm{CH}_{4}$ and $\mathrm{NO}_{2}$ emission $\left(\mathrm{CO}_{2}\right.$ equivalent on the basis of GWP), low land rice ecosystem act as net $\mathrm{C}$ sink (Bhattacharyya et al. 2014; Swain et al. 2016).

\section{Nitrogen fixation}

Nitrogen fixation is a process by which the Earth's atmosphere $\mathrm{N}_{2}$ is converted into ammonia $\left(\mathrm{NH}_{3}\right)$ or other organic forms available to crop plants (Postgate 1998). Nitrogen fixation by growing legumes was also reported from arable farming (Sandhu et al. 2008). We observed that the value of ES due to nitrogen fixation in rice farms varied from US\$ $1 \mathrm{ha}^{-1}$ year $^{-1}$ in the NEG zone, 
where rice is mostly cultivated as a monocrop to US\$ 10 ha $^{-1}$ year $^{-1}$ in NCP, with rice-pulses as major cropping system. These values are negligible $(\sim 1 \%)$ compared to marketed ES. On the basis of market price of chemical fertilizer, an annual value of about US\$ $13.65 \mathrm{ha}^{-1}$ year $^{-1}$ for biological nitrogen fixation services was reported from Ecological Station of Jatai (Santos et al. 2001). Symbiotic relationships with $\mathrm{N}$-fixing bacteria can enhance nitrogen availability through fixation of nitrogen from the atmosphere, but some free-living soil bacteria can also fix atmospheric nitrogen in to the soil (Zhang et al. 2007; Vitousek et al. 2002).

\section{Soil fertility}

For sustainable agricultural production, soil fertility plays a major role. Better agronomic management such as organic farming, crop rotation, cultivation of legumes, chemical fertilization, etc. can maintain or improve soil fertility and increase grain yield (Swinton et al. 2007; Xiao et al. 2011). In this study, the highest value for soil fertility services was observed in the NCP zone (US\$ 487 $\mathrm{ha}^{-1}$ year $^{-1}$ ), which might be due to the rice-pulse cropping system compared to the mono-cropping system in the NEG zone (US\$ $64 \mathrm{ha}^{-1}$ year $^{-1}$ ). In earlier studies, ES in terms of soil fertility was estimated at US\$ $281 \mathrm{ha}^{-1}$ from cultivated land (Ploeg and de Groot 2010).

\section{Hydrological flow}

Hydrological flow renews the water supply to the ecosystem by buffering and moderating of the hydrological cycle, which includes water infiltration into soils and aquifers, moderation of runoff, and plant transpiration (Garbach 2014). A bunded and flooded rice field can also be considered as micro-water harvest structure and as a major source of groundwater recharge (Tzia 1993). In eastern India, rice is cultivated mostly in small bunded fields that facilitate the recharge of rain water by increasing the residence time. In this study, the economic value of the hydrological flow service ranged from US\$ 11 to $12 \mathrm{ha}^{-1}$ year $^{-1}$ among four rice ACZs (Table 3), which is negligible ( 1\%) compared to marketed ES. The primary reasons behind the different values of ES for hydrological flow may be due to the different soil types and water intake capacities of soil in different geographical situations. It has been reported that abandonment of rice fields resulted in reduction of groundwater recharge (Imaizumi et al. 2006); the recharge could be enhanced by prolonging the submerged period of paddies and bringing fallow land under rice cultivation (Tanaka et al. 2010). Sandhu et al. (2008) reported ES from hydrological flow service was US\$ 54 $\mathrm{ha}^{-1}$ year $^{-1}$ from conventional fields. Similarly, the ES for hydrological flow in cereals and pastures were US\$ $86 \mathrm{ha}^{-1} \mathrm{year}^{-1}$ and US\$ $76 \mathrm{ha}^{-1} \mathrm{year}^{-1}$, respectively (Porter et al. 2009). Mondal and Nalatwadmath (2014) estimated intangible benefits from watersheds (of about 500 ha in semi-arid region of India) using indirect/non-market valuation methods to the extent of US\$15,199 year $^{-1}$, and suggested concerted measures for moderation of hydrological flow, soil and water conservation, reducing soil erosion, etc.

\section{Soil erosion}

Soil loss through erosion is a major disservice to the environment. Erosion can be caused by raindrops, runoff due to a change of crops, and faulty agronomic practices. But the rice-based cropping systems had a significant lower level of soil loss compared to the regional average due to small plot size and the use of bunded systems for rice cultivation. The variation in soil loss from rice field in this study was mainly due to soil type, topographic situation, and cropping system followed. In the high rain fall area of the eastern region, the bunded system of rice cultivation not only reduced soil erosion but also enhanced water recharge due to an increased residence period. Soil erosion of different ACZs varied from $7.5 \mathrm{t} \mathrm{ha}^{-1}$ year $^{-1}$ in NWP to $30 \mathrm{t} \mathrm{ha}^{-1}$ year $^{-1}$ in NCP. In this study, the economical value of soil erosion service was ranged from US\$ -4.2 to $-2.1 \mathrm{ha}^{-1}$ year $^{-1}$ among four rice ACZs (Table 3), which is negligible $(<1 \%)$ compared to the marketed ES. Bunded rice plots modified the sediment delivery ratio and reduced the soil loss, resulting in a lower negative economic value of soil erosion. A study conducted in Japan found that environmental function of agriculture with regard to erosion control was valued as US\$ 4147 million (Natuhara 2013) over the whole country. Another study in Japan reported that the willingness to pay for prevent soil erosion service was US\$ 3.9 per household (Aizaki et al. 2006).

\section{Land holding classes vs farm income}

Farm income accounts for provisioning services from the rice field through sale of commodities in the market. Difference in productivity and local market price of commodities caused the variation in farm income, which ranged from US\$ $523 \mathrm{ha}^{-1}$ year $^{-1}$ in NEG to US\$ 795 $\mathrm{ha}^{-1}$ year $^{-1}$ in NECP, with mean of US\$ $672 \mathrm{ha}^{-1}$ year $^{-1}$. The average farm household income of India was estimated to be INR 6426 (100 \$) per month $=1200$ US\$ year $^{-1}$ (NSSO 2013). Among the studied ACZs, a wide difference in agricultural income was found between different land holding classes. Our study revealed that marginal farmers are economically more efficient than large landholders in the area where rain-fed pulse crops, such as green gram (Vigna radiata) and black gram (Vigna mungo), are grown after rice. In the irrigated area, where intensive rice-rice-vegetable farming is practiced (the NWP zone), the average household income of 
large landholders was higher than the marginal landholders. Experience with agricultural intensification over recent decades has reflected the importance of institutional policy in the transformation and growth of agricultural production systems (FAO 2011).

\section{Economic gap analysis}

Total ES values differ significantly among different ACZs leading to the economic gaps that include both maximum and minimum economic gaps. The maximum economic gap of ES for rice farming was higher in the NCP zone (US\$ $1063 \mathrm{ha}^{-1}$ year $^{-1}$ ) (Table 4) due to higher total ES value. Similarly, the minimum ecosystem service gap was highest for NEG (US\$ $573 \mathrm{ha}^{-1}$ year $^{-1}$ ) and lowest for the NECP zone (US\$ $257 \mathrm{ha}^{-1}$ year $^{-1}$ ). These gaps can be bridged by enhancing provisioning services through agro-ecological intensification, better management practices to sustain and enhance positive ES and minimization of negative ES/disservices to the environment, value addition, and improved market access. Globally, there has been a recent focus on policy and institutional innovation to support and promote sustainable agriculture. Payment for environmental/ecosystem services (PES) is an initiative that has been started in many countries to provide incentives for the provision of positive environmental externalities. PES may be a good option for supporting sustainable agricultural development in developing countries. The PES schemes exists in different parts of world, such as China and the UK for carbon sequestration; South Africa and Mexico for watershed protection; and the USA, Costa Rica, and Nicaragua for biodiversity conservation (Kinzig et al. 2011). Different agri-environmental policies in the USA and the European Union were taken in to consideration for environmental services payments, which pay farmers to minimize the negative externalities of agricultural production, by transferring public funds to farmers. In countries like the USA, Europe, and China, large Govt. PES programmes totalling about US \$ 20 billion exists to support watershed protection, biodiversity conservation, and esthetic protection (Milder et al. 2010). However, in India, no such programmes exists because of lack of studies on assessment of valuation of ES and associated PES. This paper is an attempt to sensitize stakeholders and policy makers and academia for conducting further studies for assessment of ES from different farming and natural systems for development of effective PES programme. In India, about $70 \%$ of all community households depend on farm income which is primarily from crop cultivation. The farm incomes of agricultural crops mostly depend on the MSP value that covers only few crops fixed by the government. The small farmers are not able to sell their produce at government procurement centers and are forced to sell their produce to the middlemen at a price lower than the MSP. Hence, there is a need to compensate farmers by devising PES methodology on the basis of these gaps in income to promote sustainable agricultural development, while at the same time protecting and enhancing ES.

\section{Conclusions}

The total economic value per unit area ES of the rice fields of eastern India ranged from US\$ 1238 to 1688 $\mathrm{ha}^{-1}$ year $^{-1}$. If ecosystem services provided by rice-based system on esthetic, artistic, educational, and spiritual aspect (Cultural), $\mathrm{CO}_{2} / \mathrm{O}_{2}$ balance (gas regulation), and maintaining the flora and fauna diversity (biodiversity) were analyzed, the value of non-marketed ecosystem would have been much higher. Differential value of ES parameters can explain the variability in ecosystem services and farmer's income among the ACZs in eastern India. Clustering of locations and individual ES helps in identifying the intervention points for sustaining and improving the ES while ensuring sustainable agro-ecological intensification. This will sensitize the policy makers and the stake holders about the importance of ES and the value accrued to the society and need for maintaining and enhancing it. This will promote both the sustainability of ecosystems and agricultural development. There is also a need for more studies at local and regional level to represent site-specific characteristics of ecosystem services and development of methodology for PES.

\section{Additional file}

Additional file 1: Table S1. Sources of uncertainty in estimating the ecosystem services. (DOCX $18 \mathrm{~kb}$ )

\section{Abbreviations \\ ACZs: Agro-climatic zones; CER: Carbon emission ratio; ES: Ecosystem services; ETL: Economic threshold level; GOI: Government of India; LCA: Life cycle analysis; MSP: Minimum support prices; NCP: North central plateau; NWP: North western plateau; NEG: North eastern ghat; NSSO: National sample survey; PES: Payment for ecosystem services; PCA: Principal component analysis; SDR: Sediment delivery ratio}

\section{Acknowledgements}

Authors acknowledge the financial help provided by Ministry of Earth Sciences, Govt. of India and also thank Director General, Indian Council of Agricultural Research (ICAR) and Director, ICAR-National Rice Research Institute (NRRI) for giving all the necessary help in executing the work. The help provided by Odisha state officials in carrying out the survey work is gratefully acknowledged. This study is a part of the project entitled "Delivering food security on limited land (DEVIL; Belmont Forum / FACCE-JPI via NERC: NE/M021327/1).

Availability of data and material Most of the data generated or analyzed during this study are included in this published article. 


\section{Authors' contributions}

AKN, MS, and RT conceptualized the idea and designed this study. ADN, BD, and KCM collected and analyzed the samples. AKN, MS, RT, and SDM interpreted the analyzed data. AKN, RT, ADN, BD, and MS drafted manuscript. BM and NNJ helped in statistical analysis. AKS, PB, NF, PS, and HP revised the manuscript. All authors read and approved the final manuscripts submitted to the journal.

\section{Funding}

Ministry of Earth Sciences, Govt. of India has funded the project under which this study was conducted. The fund agency does not have any roles in the design of the study and collection, analysis, and interpretation of data and in writing the manuscript.

\section{Ethics approval}

Not applicable

\section{Consent for publication}

Not applicable

\section{Competing interests}

The authors declare that they have no competing interests.

\section{Author details}

'ICAR-National Rice Research Institute, Cuttack, Odisha 753006, India. ${ }^{2}$ Indian Institute of Soil Sciences, Nabibagh, Bhopal, Madhya Pradesh, India. Institute of Biological \& Environmental Sciences, University of Aberdeen, 23 St Machar Drive, Aberdeen AB24 3UU, UK.

\section{Received: 30 January 2019 Accepted: 30 July 2019}

\section{Published online: 02 September 2019}

\section{References}

Aizaki H, Sato K, Osari H (2006) Contingent valuation approach in measuring the multifunctionality of agriculture and rural areas in Japan. Paddy Water Environ 4:217-222. https://doi.org/10.1007/s10333-006-0052-8

Barrios E (2007) Soil biota, ecosystem services and land productivity. Ecol Econ 64:269-285

Bhattacharyya P, Neogi S, Roy KS, Dash PK, Nayak AK, Mohapatra T (2014) Tropical low land rice ecosystem is a net carbon sink. Agric Ecosyst Environ 189:127-135. https://doi.org/10.1016/j.agee.2014.03.013

Bhola K, Malhotra R (2014) Carbon credit capital: Indian commodity market 2020. Middle-East J Sci Res 22 1622-1629. https://doi.org/10.5829/idosi.mejsr.2 014.22.11.21626

Bianchi FJJA, Booij CJH, Tscharntke T (2006) Sustainable pest regulation in agricultural landscapes: A review on landscape composition, biodiversity and natural pest control. Proc Royal Society B Biol Sci 273:1715-1727. https://doi. org/10.1098/rspb.2006.3530

Brady NC, Weil RR (2004) Elements of the nature and properties of soils, Second ed. Prentice Hall, New Jersey

Breemen NV, Buurman P (2002) Soil Formation, Second ed. Kluwer Academic Publishers, Dordrecht

Chaplin-Kramer R, Kliebenstein DJ, Chiem A (2011) Chemically mediated tritrophic interactions: Opposing effects of glucosinolates on a specialist herbivore and its predators. J Appl Ecol 48:880-887.

Costanza R, d'Arge R, de Groot R, Farber S, Grasso M, Hannon B, Limburg K, Naeem S, O'Neill RV, Paruelo J, Raskin RG, Sutton P, van den Belt M (1997) The value of the world's ecosystem services and natural capital. Nature 387 253-260.

Daily GC, Alexander S, Ehrlich PR, Goulder L, Lubchenco J, Matson PA, Mooney HA, Postel S, Schneider SH, Tilman D, Woodwell GM (1997) Ecosystem services: benefits supplied to human societies by natural ecosystems. Issues in Ecology 2:2-15

de Groot R, Brander L, van der Ploeg S, Costanza R, Bernard F, Braat L (2012) Global estimates of the value of ecosystems and their services in monetary units. Ecosyst Serv 1:50-61.

Department of Water Resources (2015) Odisha, district irrigation plan (DIP) of Odisha, http://www.dowrorissa.gov.in/DIP/DIPIndex.htm. (Accessed 23rd Aug 2017)

Devi Pl, Kumar L, Kumar DS, Manjula M, Mukhopadhyay P, Raghu P, Sharma D, Sridhar R, Venkatachalam L (2017) Payment for ecosystem services guaranteed farm income and sustainable agriculture. Economic Political Weekly LII 17

Drake DJ, Nader G, Forero L (2002) Feeding rice straw to cattle. ANR UC Davis 8079

Dubey A, Lal R (2009) Carbon footprint and sustainability of agricultural production systems in Punjab, India, and Ohio, USA. J Crop Improve 23:332350

Edwards CA (2004) The importance of earthworms as key representatives of the soil fauna. In: Edwards CA (ed) Earthworm Ecology. CRC Press, Florida, pp 3-11

FAO (2004) Water charging in irrigated agriculture, FAO water reports 28 accessed at http://www.fao.org/docrep/008/y5690e/y5690e0b.htm.

FAO (2005) Fertilizer use by crop in India. First version, published by FAO, Rome. http://www.fao.org/docrep/009/a0257e/A0257E05.htm

FAO (2011) Payments for environmental services. In: What role in sustainable agricultural development. http://www.fao.org/3/a-an456e.pdf

Franco AA, Balieiro FDC (2000) The role of biological nitrogen fixation in land reclamation, agroecology and sustainability of tropical agriculture. Transition to global sustainability: the contribution of Brazilian science. p. 209-233.

Fraser PM, Williams PH, Haynes RJ (1996) Earthworm species, population size and biomass under different cropping systems across the Canterbury Plains, New Zealand. Appl Soil Ecol 3:49-57.

Garbach K (2014) Biodiversity and Ecosystem Services in Agroecosystems. Encyclopedia Agric Food Systems 2:21-40. https://doi.org/10.1016/B9780-444-52512-3.00013-9

Garcia-Torres L, Benites J, Martinez-Vilela A, Holgado-Cabrera A (2003) Conservation agriculture: environment, farmers experiences, innovations, socio-economy, policy. Kluwer Academia Publishers; Dordrecht, The Netherlands; Boston, Germany; London, UK.

Government of India (GOI), Ministry of Agriculture (2016) Agricultural Statistics at a Glance 2016:83-84 Available at: http://eands.dacnet.nic.in/ PDF/Glance-2016.pdf

Gurr GM, Wratten SD, Altieri MA. (Eds.) (2004) Ecological engineering for pest management: advances in habitat manipulation for arthropods. CSIRO, Victoria.

Haines-Young R, Potschin M (2010) The links between biodiversity, ecosystem services and human well-being. In: Raffaelli D, Frid C (eds) Ecosystem ecology: a new synthesis, BES Ecological Reviews Series. CUP, Cambridge

Herrick JE, Lal R (1996) Dung decomposition and pedoturbation in a seasonally dry tropical pasture. Biol Fertil Soils 23:177-181

Hillier J, Hawe C, Squire G, Hilton A, Wale S, Smith P (2009) The carbon footprints of food crop production. Inter J Agric Sustain 7:107-118

ICAR/DARE Annual Report (2006-2007) Natural resource management. Available http://www.icar.org.in/files/ar0607/03-NRM.pdf.

Imaizumi M, Ishida S, Tuchihara T (2006) Long-term evaluation of the groundwater recharge function of paddy fields accompanying urbanization in the Nobi Plain, Japan. Paddy Water Environ 4:251-263

IPCC (2006) National Greenhouse gas inventories: Land use, land use change and forestry. Institute of Global Environmental Strategies, Hayama, Japan

Johnson JMF, Allmaras RR, Reicosky DC (2006) Estimating source carbon from crop residues, roots and rhizodeposits using the national grain-yield database. Agronomy J 98:622-636. https://doi.org/10.2134/agronj2005.0179

Kathuria V (2015) Environmental cost of using top-soil for brick making - a case study from India problem /issue ? Review Market Integration 5:171-201. https://doi.org/10.1177/0974929214521892

Keeney DR, Nelson DW (1982) Nitrogen-inorganic forms. In: Page, A.L., Miller, R. H. , Keeney, D.R. (Eds.), Methods of soil analysis. Part 2. Chemical and microbiological properties-agronomy monograph, No. 9. ASA and SSSA, Madison, Wisconsin U.S.A. p. 643-698.

Kinzig AP, Perrings C, Chapin III. F.S, Polasky. S, Smith. V.K, Tilman, D, and Turner. B.L (2011) Paying for ecosystem services_-promise and peril. Science 334: 603-604. https://doi.org/10.1126/science.1210297

Kratz W (1998) The bait-lamina test: general aspects, applications and perspectives. Environ Sci Poll Res 5:94-96

Krishna W, Byju NG, Tamizheniyan S (2003) Integrated pest management in Indian agriculture: a developing economic perspective. In: Radcliff EB, Hutchson WD (eds) IPM World Text book, St Paul, Minnesota Available at: https://ipmworld.umn.edu/krishna-indian-ag

La Notte A, D'Amato D, Mäkinen H, Paracchini ML, Liquete C, Egoh B, Geneletti D, Crossman ND (2017) Ecosystem services classification: a systems ecology perspective of the cascade framework. Ecol Ind 74:392-402

Lakshmi CSR, Rao PC, Sreelatha T, Madahvi M, Padmaja G, Rao PV, Sireesha A (2012) Nitrogen use efficiency and production efficiency of rice under 
rice-pulse cropping system with integrated nutrient management. J Rice Res 5:42-51

Landers DH, Nahlik AM (2013) Final ecosystem goods and services classification system .(FEGS-CS), in Anonymous EPA United States Environmental Protection Agency. In: Report Number EPA/600/R-13/ORD-004914

Lee KE (1985) Earthworms: their ecology and relationships with soils and land use, vol 411. Academic Press, Sydney

Letourneau DK, Jedlicka JA, Bothwell SG, Moreno CR (2009) Effects of natural enemy biodiversity on the suppression of arthropod herbivores in terrestrial ecosystems. Ann Rev Ecol Evol Syst 40:573-592

Loc HH, Diep NTH, Can NT, Irvine KN, Shimizu Y (2016) Integrated evaluation of ecosystem services in prawn-rice rotational crops, Vietnam. Ecosyst Serv 26: 377-387. https://doi.org/10.1016/j.ecoser.2016.04.007

Ma S, Swinton SM, Lupi F (2012) Farmer's willingness to participate in paymentfor-environmental-services programmes. J Agric Econ 63: 604-626. https:// doi.org/10.1111/j.1477-9552.2012.00358.x

Magdoff F, Weil RR (eds) (2004) Soil organic matter in sustainable agriculture. CRC Press, Boca Raton, Florida, pp 1-43

Mala M, Jahan M, Islam KS (2009) Comparative prey consumption of a predatory spider, Pardosa pseudoannulata (bosenberg and strand) on three different diets. Prog Agric 20: 57-62. https://doi.org/10.3329/pa.v2 0i1-2.16850

Mandal B, Majumder B, Adhya TK, Bandyopadhyay PK, Gangopadhyay A, Sarkar D, Kundu MC, Choudhury SG, Hazra GC, Kundu S, Samantaray SN, Mishra AK (2008) Potential of double-cropped rice ecology to conserve organic carbon under subtropical climate. Global Change Biol 14:2139-2151. https://doi. org/10.1111/j.1365-2486.2008.01627.x

Mantanis G, Nakos P, Berns J, Rigal L (2000) Turning agricultural straw residues into value added composite products: a new environmantally friendly technology. In: Anagnostopoulos A (ed) Proc. Fifth Inter. Conf. Environ. Poll. Thessaloniki, Greece

Manzanilla DO, Paris TR, Vergara GV, Ismail AM, Pandey S, Labios RV, Tatlonghar GT, Acd RD, Chi TTN, Duoangsila K, Siliphouthone I, Manikmas MOA, Mackill DJ (2011) Submergence risks and farmers' preferences: Implications for breeding Sub1 rice in Southeast Asia. Agric Sys 104:335-347

McTaggart D, Findlay C, Parkin M (2003) Economics, fourth ed. Pearson Education, Australia

MEA (Millennium Ecosystem Assessment) (2003) Ecosystems and Human wellbeing: a Framework for Assessment. World Resources Institute, Washington, D.C

MEA (Millennium Ecosystem Assessment) (2005) Ecosystems and human wellbeing: biodiversity synthesis. World Resources Institute, Washington, D.C

Mondal B., Nalatwadmath SK (2014) How much is a watershed worth? An assessment. Indian J Soil Con 42:322-327

Mononen L, Auvinen AP, Ahokumpu AL, Rönka M, Aarras N, Tolvanen G, Kamppinen M, Viirret E, Kumpula T, Vihervaara P (2016) National ecosystem service indicators: measures of social-ecological sustainability. Ecol Ind 61:2737

Myers N (1996) Environmental services of biodiversity. Proc Nat Acad Sci 93 2764-2769

National Bank for Agriculture and Rural Development (NABARD, 2017). NABARD all india rural financial inclusion survey 2016-17, Mumbai, 1-112. Access at https://www.google.com/url?sa=t\&rct=j\&q=\&esrc=s\&source=web\&cd= $1 \& c a d=r j a \& u a c t=8 \& v e d=2$ ahUKEwjPtO3yrHiAhX56nMBHShSAPwQFjAAegQIB RAC\&url=http\%3A\%2F\%2Fwww.nabard.org\%2Fauth\%2Fwritereaddata\%2 Ftender\%2F1608180417NABARD-Repo 16_Web_P.pdf\&usg=AOvVaw3 CCSJtM0Js-y0DOINnsV52

Natuhara $Y$ (2013) Ecosystem services by paddy fields as substitutes of natural wetlands in Japan. Ecol Eng 56:97-106. https://doi.org/10.1016/j.ecoleng.2 012.04 .026

Nayak AK, Gangwar B, Shukla AK (2012) Long-term effect of different integrated nutrient management on soil organic carbon and its fractions and sustainability of rice-wheat system in Indo Gangetic Plains of India. Field Crops Res 127:129-139

NSSO (2013) Key indicators of land and livestock holdings in India. 70th National Sample Survey Office, Ministry of Statistics and Programme Implementation. Government of India.

Ozyuguran A, Acma HH, Dahiloglu E (2014) Production of fuel briquettes from ricehusk-lignite blends. Environ Sci Technol 33:482-489

Pathak H, Chakrabarti B, Mina U, Pramanik P, Sharma DK (2017) Ecosystem services of wheat (Triticum aestivum) production with conventional and conservation agricultural practices in the Indo-Gangetic Plains. Indian J Agric Sci 87:987-991

Pathak H, Jain N, Bhatia A, Patel J, Aggarwal PK (2010) Carbon foot prints of Indian food items. Agric Ecosys Environ 139:66-73. https://doi.org/10.1016/j. agee.2010.07.002

Pimentel D, Harvey C, Resosudarm P, Sinclair K, Kurz D, McNair M, Crist S, Shpritz L, Fitton L, Saffouri R, Blair R (1995) Environmental and economic costs of soil erosion and conservation benefits. Science 267:1117-1125

Ploeg VD, de Groot R (2010) The TEEB valuation database: a searchable database of 1310 estimates of monetary values of ecosystem services. Foundation for Sustainable Development, Wageningen, Netherlands. https://www.espartnership.org/services/data-knowledge-sharing/ecosystem-servicevaluation-database/. (Accessed 25 Aug 2017)

Porter J, Costanza R, Sandhu H, Sigsgaard L, Wratten S (2009) The value of producing food, energy, and ecosystem services within an agro-ecosystem. Ambio 38:186-193. https://doi.org/10.1579/0044-7447-38.4.186

Postgate J (1998) Nitrogen Fixation, 3rd edn. Cambridge University Press, Cambridge

Raju DSR, Reddy VR, Reddy PP, Reddy MS (2005) Water use efficiency: a study of system of rice intensification (SRI) adoption in Andhra Pradesh. Ind J Agric Econ 60:458-472

Ravichandran M, Sriramachandrasekharan MV (2011) Optimizing timing of potassium application in productivity enhancement of crops of Karnataka. J Agric Sci 24:75-80

RBI (2017) Dollar conversion to INR as on 2017-04-24. https://www.rbi.org.in/ scripts/ReferenceRateArchive.aspx.

Reid WV, Mooney HA, Cropper A, Capistrano D, Carpenter SR, Chopra K, Dasgupta P, Dietz T, Duraiappah AK, Hassan R, Kasperson R, Leemans R, May RM, McMichael AJ, Pingali P, Samper C, Scholes R, Watson RT, Zakri AH, Shidong Z, Ash NJ, Bennett E, Kumar P, Lee MJ, Raudsepp-Hearne C, Simons $H$, Thonell J, Zurek NB (2005) Millennium Ecosystem Assessment Synthesis Report. Island Press, Washington.

Ribaudo M, Greene C, Hansen L, Hellerstein D (2010) Ecosystem services from agriculture: Steps for expanding markets. Ecol Econ 69:2085-2092

Roger PA, Ladha JK (1992) Biological $N_{2}$ fixation in wetland rice fields: estimation and contribution to nitrogen balance. Plant Soil 141:41-55. https://doi.org/1 $0.1007 / B F 00011309$

Root RB. (1967) The niche exploitation pattern of the blue-gray gnatcatcher. Ecol Monogr 37:317-350

Roy RN, Finck A, Blair GJ, Tandon HS (2006) Plant nutrition for food security: a guide to integrated nutrient management. FAO Fertilizer \& Plant Nutrition Bulletin, No. 16, Food and Agriculture Organization of the United Nations, Rome, Italy.

Sandhu HS, Wratten D, Cullen R, Case B, Case B (2008) The future of farming : the value of ecosystem services in conventional and organic arable land, An experimental approach. Ecol Econ 64:835-848. https://doi.org/10.1016/j. ecolecon.2007.05.007

Sandhu HS, Wratten SD, Cullen R (2005) Evaluating ecosystem services on farml and: a novel, experimental, "bottom-up" approach', shaping sustainable systems. Proceedings of the 15th IFOAM Organic World Congress. 20-23 September 2005, Adelaide Australia, (September 2005). http://orgprints.org/ view/projects/int-isofar.html.

Santos JE, Nogueira F, Pires JS, Obara AT, Pires AMZCR (2001) The value of the Ecological Station of Jatai's ecosystem services and natural capital. Brazilian J Biol 61:171-190. doi: https://doi.org/10.1590/S0034-71082001000200002

Sarnklong C, Coneja JW, Pellikaan W, Hendriks WH (2010) Utilization of rice straw and different treatments to improve its feed value for ruminants: a review. Asian-Australasian J Animal Sci 23:680-692. https://doi.org/10.5713/ajas.2010. 80619

SAS (2008) Stistical Analysis Software,Version 9.2 of the SAS System for Windows. SAS Institute Inc, Cary, NC, USA

Shahid M, Nayak AK, Puree C, Tripathi R, Lal B, Gautam P, Bhattacharyya P, Mohanty S, Kumar A, Panda BB, Kumar U, Sukla AK (2017) Carbon and nitrogen fractions and stocks under 41 years of chemical and organic fertilization in a sub-humid tropical rice soil. Soil Till Res 170:136-146

Shepard BM, Barrion AT, Litsinger JA (1987) Helpful insects, spiders, and pathogens. Manila (Philippines). International Rice Research Institute, p 127

Singaravadivel K (2016) Rice processing and value addition in India. Fnbnews. com 04.03.2016. http://www.fnbnews.com/Top-News/rice-processing-andvalue-addition-in-india-38593

Singh L S Singh N (2016) Economic transformation of a developing economy: the experience of Punjab, India. Springer, Singapore, pp 1-400 
Singh NP, Praharaj CS, Sandhu JS (2016) Utilizing untapped potential of rice fallow of East and North-east India through pulse production. Indian J Genetics Plant Breeding 76:388-398. https://doi.org/10.5958/0975-6906.2016. 00058.4

Singh Y, Sidhu HS (2014) Management of cereal crop residues for sustainable rice-wheat production system in the Indo-Gangetic Plains of India. Proc Indian Nat Sci Academy 80:95-114. https://doi.org/10.16943/ptinsa/2014/ v80i1/55089

Soni P, Taewichit C, Salokhe, Vilas M (2013) Energy consumption and $\mathrm{CO}_{2}$ emissions in rainfed agricultural production systems of Northeast Thailand. Agric Syst 116:25-36. https://doi.org/10.1016/j.agsy.2012.12.006

Southwood TRE (1978) Ecological Methods. Chapman and Hall, London, England

Spangenberg JH, Settele J (2010) Precisely incorrect? Monetising the value of ecosystem services. Ecol Compl 7:327-337

Spangenberg JH, von Haaren C, Settele J (2014) The ecosystem service cascade: Further developing the metaphor. Integrating societal processes to accommodate social processes and planning, and the case of bioenergy. Ecol Econ 104:22-32

Sreenivasalu, Vemu UB (2012) Sediment yield estimation and prioritization of watershed using RS and GIS. Inter. Arch. Photogrammetry, Remote Sensing Spatial Infor. Sci. XXXIX-B8, 529-533. https://doi.org/10.5194/isprsarchivesXXXIX-B8-529-2012

Stallman HR (2011) Ecosystem services in agriculture: determining suitability for provision by collective management. Ecol Econ 71:131-139

Stockdill SMJ (1982) Effects of introduced earthworms on the productivity of New Zealand pastures. Pedobiologia 24:29-35

Stubbs A, Chandler P (1978) A dipterist's handbook. In: The Amateur Entomologists' Society, vol 15. UK, p 255

Swain C, Bhattacharyya P, Singh N, Neogi S, Sahoo R, Nayak AK, Zhang G, Leclerc M (2016) Net ecosystem methane and carbon dioxide exchange in relation to heat and carbon balance in lowland tropical rice. Ecol Eng 95:364-374. https://doi.org/10.1016/j.ecoleng.2016.06.053

Swinton SM, Lupi F, Robertson GP, Hamilton SK (2007) Ecosystem services and agriculture: Cultivating agricultural ecosystems for diverse benefits. Ecol Econ 64:245-252 https://doi.org/10.1016/j.ecolecon.2007.09.020

Tanaka K, Funakoshi Y, Hokamura T, Yamada F (2010) The role of paddy rice in recharging urban groundwater in the Shira River Basin. Paddy Water Environ 8:217-226

TEEB (2010) The Economics of Ecosystems and Biodiversity. Ecological and Economic Foundations, Routledge Abingdon, UK, pp. 410

Tilman D, Cassman KG, Matson PA, Naylor R, Polasky S (2002) Agricultural sustainability and intensive production practices. Nature 418:671-677

Torne E (1990) Assessing feeding activities of soil-living animals: I. Bait-lamina tests. Pedobiologia 34:89-101

Tripathi KP (2016) Field bunding: foremost rain water management measure. In: Singh N. Kumar A. et al., (Eds.), Water Conservation and Management in India, The institute of Engineers (India), Annual Technical. Vol II, pp.34-40

Tzia MH (1993) The contribution of rice paddy field irrigation to society in Taiwan. Council of Agriculture, Taiwan

UK NEA (2011) UK National ecosystem assessment: technical report. UNEP-WCMC Vinod KK, Heuer S (2012) Approaches towards nitrogen and phosphorusefficient rice. AoB Plants, 2012:pls028. https://doi.org/10.1093/aobpla/pls028

Vitousek PM, Cassman K, Cleveland C, Crews T, Field CB, Grimm NB, Howarth RW, Marino R, Martinelli L, Rastetter EB, Sprent JI (2002) Towards an ecological understanding of biological nitrogen fixation. Biogeochemistry 57/58:1-45

Wossink A, Swinton SM (2007) Jointness in production and farmers' willingness to supply non-marketed ecosystem services. Ecol Econ 64:297-304

Xiao Y, Kai A, Gaodi X, Chunxia L (2011) Evaluation of ecosystem services provided by 10 typical rice paddies in China. J Resour Ecol 2:328-337. https://doi.org/10.3969/j.issn.1674-764x.2011.04.006

Yan M, Luo T, Bian R, Cheng K, Pan G, Rees. R (2015) A comparative study on carbon footprint of rice production between household and aggregated farms from Jiangxi, China. Environ Monit Assess 187:332. https://doi.org/10.1 007/s10661-015-4572-9

Yan XY, Cai ZC, Ohara T, Akimoto H (2003) Methane emission from rice fields in mainland China: amount and seasonal and spatial distribution. J Geophys Res 108(D16):4505

Zhang R, Li X, Fadel JG (2002) Oyster mushroom cultivation with rice and wheat straw. Biores Technol 82:277-284
Zhang W, Ricketts TH, Kremen C, Carney K, Swinton SM (2007) Ecosystem services and dis-services to agriculture. Ecol Econ 64:253-260. https://doi. org/10.1016/j.ecolecon.2007.02.024

Zou JW, Huang Y, Zheng XH, Wang YS (2007) Quantifying direct $\mathrm{N}_{2} \mathrm{O}$ emissions in paddy fields during rice growing season in mainland China: dependence on water regime. Atmos Environ 41:8030-8042

\section{Publisher's Note}

Springer Nature remains neutral with regard to jurisdictional claims in published maps and institutional affiliations.

\section{Submit your manuscript to a SpringerOpen ${ }^{\circ}$ journal and benefit from:}

- Convenient online submission

- Rigorous peer review

- Open access: articles freely available online

- High visibility within the field

- Retaining the copyright to your article

Submit your next manuscript at $\boldsymbol{\nabla}$ springeropen.com 